\title{
Moutabea chartacea (Polygalaceae), a new species from the north-central Amazon and Guayana Shield
}

\author{
(D) Gerardo A. Aymard C. ${ }^{1, *}$, (D) Lisa M. Campbell² \\ ${ }^{1}$ UNELLEZ-Guanare, Programa de Ciencias del Agro y del Mar, Herbario Universitario (PORT), \\ Mesa de Cavacas, Estado Portuguesa, Venezuela \\ ${ }^{2}$ The New York Botanical Garden, Bronx, NY, U.S.A.
}

\begin{abstract}
We describe and illustrate Moutabea chartacea from the wet lowland forests of Brazil (Amazonas state), Venezuela (Amazonas, Bolívar and Delta Amacuro states), and Colombia (Caquetá, Meta and Vaupés departments), and we discuss its morphological relationships with an allied species. This new species is similar to M. gentryi, but it differs by its smaller petioles, leaf blades, calyx lobes, fruit, and seeds; triangular bracts; petals not reflexed; and the seed densely covered by stellate trichomes. An updated key to the named species of Moutabea is provided. C 2018. Acad. Colomb. Cienc. Ex. Fis. Nat.
\end{abstract}

Key words: Brazil; Colombia; Flora of the Venezuelan Guayana; Moutabea; Polygalaceae; Wet lowland forests.

Moutabea chartacea (Polygalaceae), una nueva especie de la Amazonía nor-central y el escudo guayanés

Resumen

Se describe e ilustra la especie Moutabea chartacea, de los bosques húmedos de tierras bajas de Brasil (estado Amazonas), Venezuela (estados Amazonas, Bolívar y Delta Amacuro) y Colombia (departamentos de Caquetá, Meta y Vaupés), y se discuten sus relaciones morfológicas con su especie afín. Esta nueva especie es similar a M. gentryi, sin embargo, difiere por poseer los pecíolos, hojas, lóbulos de cáliz, frutos y semillas más pequeños, así como brácteas triangulares, pétalos con los ápices no reflexos y semillas densamente cubiertas por tricomas estrellados. Se incluye una clave actualizada de las especies de Moutabea. (C) 2018. Acad. Colomb. Cienc. Ex. Fis. Nat.

Palabras clave: Brasil; Colombia; Flora de la Guayana Venezolana; Moutabea; Polygalaceae; bosques húmedos.

\section{Introduction}

Moutabea Aubl. (Aublet, 1775), as traditionally circumscribed is a neotropical genus of about ten (and at least two undescribed) species of lianas, rarely shrubs or small trees, distributed from Costa Rica to Bolivia (Styer, 1997; Persson \& Eriksen, 2009; Ulloa-Ulloa, et al., 2017). Several species have edible fruits (Eriksen, et al., 2000; Aymard, et al., 2004; Eriksen \& Persson, 2007). Moutabea (mainly M. guianensis Aubl.) and other genera of Polygalaceae are an important source of xanthones (Ripardo Filho, et al., $2005 ; 2014)$. These organic compounds are widely used as an insecticide, ovicide, and larvicide, as well as in the preparation of xanthydrol, which is used to determine urea levels in the blood (Williams, et al., 2000).

The genus is characterized by the combination of strictly axillary racemes, bilaterally symmetrical flowers, tubular corolla, eight stamens with the filaments fused into a sheath that is adnate to the petals, and a (2--)4(5)-locular ovary (Styer, 1977; Eriksen, 1993a; Eriksen \& Persson, 2007). Moutabea is distinguished from other Moutabeae in consistently having more pronounced bilaterally symmetrical flowers, a boat-shaped abaxial petal, bisporangiate anthers, and an upwardly curved style. Although there is variability in the number of locules, Moutabea usually has four whereas the other genera have either fewer ( 2 or 3, Balgoya and Barnhartia) or more (5 to 8, Diclidanthera and Eriandra).

Polygalaceae (Fabales; APG, 2016) are worldwide in distribution with about 27 genera and 1,200 species. The infrafamilial classification includes three long-recognized tribes and a fourth more recently segregated (Carpolobieae B.Eriksen, Moutabea Chodat, Polygaleae Chodat, and Xanthophylleae Baill.) based on cladistic analyses of morphological characters (Eriksen, 1993b) and DNA sequence data (Persson, 2001; Forest, et al., 2007 [in part]; Pastore, et al., 2017).

Moutabea has never been monographed, and no sections or subgenera have been recognized. As noted elsewhere, the "genus badly needs revision" (a note wrote by J. J. Wurdack, in

\footnotetext{
*Corresponding autor:

Gerardo A. Aymard C., cuyuni24@hotmail.com

Received: April 7,2018

Accepted: August 6, 2018

Editor: Elizabeth Castañeda
} 
C. Cid, et al. 4112, NY) including field work (Wendt, 2000). Jansen-Jacobs \& Maas (2010) assessed the taxonomy of the genus describing a new species, recognizing eleven in total, including three yet undescribed. Subsequently, M. floribunda J.C. Huber ex J.B. Silveira \& Secco was described from the rainforests of Brazil, Guyana, and Perú (Silveira \& Secco, 2015). The circumscription of Moutabea was expanded to include a species (M. pacifica (Morat \& Meijden) Byng \& Christenh.) from New Caledonia, previously treated as the monotypic genus Balgoya Morat \& Meijden (Christenhusz, et al., 2018). This change was made based on Pastore, et al. (2017) unexplained preliminary cladistic hypothesis which showed the enigmatic species of Balgoya to be nested within Moutabea in a molecular phylogenetic study. Further research includes greater taxonomic sampling and an examination of morphological characters that would support a circumscription of Moutabea (with connate sepals and petals and slightly curved style) to include Balgoya (with free sepals and petals and straight style) and recognize the combination.

Wendt (2000) pointed out several morphological leaf features that we find generally useful for separating the species into two morphological groups. However, further evaluation is needed to assess these distinctions amongst the named and recognized undescribed species (Eriksen, $\boldsymbol{e t}$ al., 2000; Aymard, et al., 2004) and address the widespread species $M$. aculeata, which possess characteristics of both groups. One group is characterized by leaves that are very dark, coriaceous to very thick-textured, without cystolithlike protuberances ("knob-like papillae" of Eriksen \& Persson, 2007), and the lateral veins immersed and not discernible or distinctly and uniformly impressed $(M$. angustifolia Huber, M. chodatiana Huber, M. dibotrya Mart. ex Miq., M. excoriata Mart. ex Miq., M. guianensis Aubl.). The second group is characterized by chartaceous to subcoriaceous, discolorous leaves, that are brown abaxially, green adaxially, with cystolith-like protuberances on both sides and the secondary veins slightly impressed to plane above and raised below (e.g., M. arianiae Jans.-Jac. \& Maas, $M$. gentryi T.Wendt).

\section{Materials and methods}

Herbarium specimens from the following institutions were studied: A, COAH, COL, GH, K, MO, MSC, NY, US, and VEN. The new species was described based on dried material and observations of other species were supplemented by relevant literature.

Taxonomy. Moutabea chartacea Aymard \& L.M. Campb., sp. nov. (Figure 1)

Type: VENEZUELA. Bolívar: 20--25 km SW of El Manteco, on road to San Pedro de las dos Bocas, $07^{\circ} 10^{\prime} \mathrm{N}$; 62 $55^{\prime}$ W, ca. $200 \mathrm{~m}, 1--3$ Aug 1978 [fl], R. Liesner \& A. González 5969 (holotype: VEN; isotypes: MO, NY, VEN).

Diagnosis: Species Moutabea gentryi T.Wendt proxima, sed diversa: petiolis ca. 1(--2) mm latis, non rugulosis, lamina
2--3.5(--5) cm lata, bracteis 1--2 mm longis, triangularibus, extus pilosis, intus glabris, calycis lobis $4--5 \mathrm{~mm}$ longis, oblongis, utrinque adpresso-pubescentibus, petalis apice haud reflexis, tubo staminali [filamento] ultra petalorum basin, abaxialiter dense piloso, fructu 2--4 cm diametro, seminibus ca. $1.5 \mathrm{~cm}$ longis, stellatis pilis dense vestitis.

Lianas (high-climbing) or lianescent shrubs. Branches and branchlets terete, glabrous, without persistent spinules, bark flaking off when mature. Leaf blades 5--20 × 2--3.5(--5 $\mathrm{cm}$ ), chartaceous, obovate to obovate-elliptic, discolorous, brown abaxially, green adaxially, base acute, apex acute, sometimes rounded, the margin entire, glabrous on both surfaces, with cystolith-like protuberances on both sides, the midvein adaxially raised proximally, plane distally, abaxially raised, secondary veins 6--18 per side, raised abaxially, slightly impressed to plane adaxially, tertiary venation not visible. Petiole 4--10 mm long, 1(--2) mm wide, glabrous, not rugulose, with two annular glands at each node in the stipular position, glands ca. $2 \mathrm{~mm}$ diam. Inflorescence 1--5 cm long, 3--8-flowered, the main axis black, striate, sparsely appressed-pilose; pedicels 1--2 mm long, pubescence as on

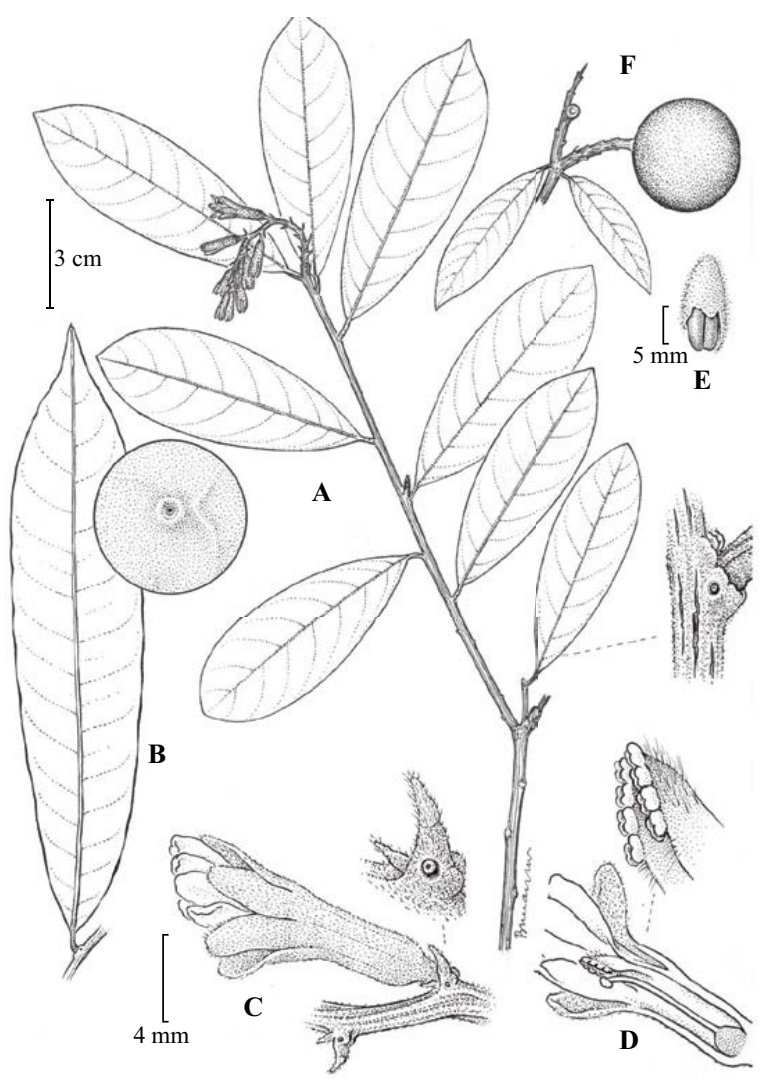

Figure 1. Moutabea chartacea. A. Branch showing the inflorescence and flowers. B. Leaf and detail showing a cystolith-like protuberance. C. Lateral view of a flower and a stipular region annular gland. D. Flower in medial view with part of the perianth removed and detail of the filament sheath and anther insertion. E. Seed with part of the aril removed. F. Branch with a fruit. (Drawn from R. Liesner \& A. González 5969). 
the main axis, bracts at the base of the pedicel (not those along the axis) 1--2 mm, triangular, pilose outside, glabrous inside, margins ciliate, with a pair of annular glands at the base adaxially, ca. $1 \mathrm{~mm}$ diam. Flower ca. $1.5 \mathrm{~cm}$ long, floral tube and calyx green, the tube ca. $1 \mathrm{~cm}$ long, puberulent to glabrescent externally; calyx lobes 4--5 mm long, oblong, appressed pubescent on both sides, margins ciliate, calyx bilaterally symmetrical, lateral sepals reclinated in outline; petal limbs ca. $5 \mathrm{~mm}$ long, white, oblong, glabrous on both surfaces, margins thickened, apex rounded, not reflexed, basally adherent to a filament sheath; staminal sheath hood free, extending ca. $2.5 \mathrm{~mm}$ beyond petal attachment, densely pilose abaxially; anthers 8, glabrous, sessile, rounded, partially coalescent basally, obliquely arranged on the sheath apex to form a V-shape; ovary ca. 1--1.3 mm long at anthesis, style $0.5-1 \mathrm{~cm}$ long, glabrous, distally slightly curved upwards, stigma flattened-capitate, included in the filament sheath. Fruit 2--4 cm diam., globose, glabrous; seed ca. $1.5 \mathrm{~cm}$ long, ovate, densely covered by stellate trichomes, surrounded by a thin aril, with the aril removed seed 5--6 mm thick.

Distribution and habitat. Known from Amazonas state, Brazil; Amazonas, Bolívar, and Delta Amacuro states, Venezuela; and Caquetá, Meta, and Vaupés departments, Colombia. Moutabea chartacea occurs in wet lowland forests (várzea and terra firme), between 100--350 m.

Taxonomic notes. In the Flora of the Venezuelan Guayana treatment of Polygalaceae (Aymard et al., 2004), Moutabea chartacea was included as "Moutabea sp. A." This new species is possibly allied to a group of specimens collected in the Amazon basin that may represent yet another undescribed taxon (Wendt, 2000). Because of its discolorous leaves, with cystolith-like protuberances on both surfaces, and the secondary veins raised abaxially and slightly impressed to plane adaxially $M$. chartacea is similar to M. gentryi from Costa Rica, Panamá, Colombia (Antioquia), and northwestern Venezuela in Zulia state (Wendt, 2000; Aymard \& Freire-F., 2016). However, $M$. chartacea differs from that species by its petioles slender, ca. 1(--2) mm wide, smooth, leaf blades $23.5(--5) \mathrm{cm}$ wide (vs. petioles stout, 2--4 mm wide, rugulose, blades 4--9 $\mathrm{cm}$ wide), bracts 1--2 mm long, triangular, pilose externally, glabrous internally, (vs. 1--3.5 mm, lanceolate or lanceolate-ovate, puberulent on both surfaces); calyx lobes 4--5 mm long, oblong, appressed-pubescent on both sides (vs. 7--9 mm, ovate, densely puberulous adaxially); petal apex not reflexed, anthers rounded (vs. petal apex strongly reflexed, anthers quadrate), fruit 2--4 cm diam., and seeds ca. $1.5 \mathrm{~cm}$ long, densely covered by stellate trichomes (vs. ca. $5 \mathrm{~cm}$ diam., seeds 2--2.6 cm, covered by a tomentum of simple trichomes).

Etymology. Moutabea chartacea is named for the texture of its leaves, in a genus with leaf blades otherwise mostly coriaceous to very thick-textured.

Phenology. Known to flower in August, October, and November; and fruit in April, May, and October.
International Union for Conservation of Nature (IUCN) Red List ${ }^{T M}$ category. According to the IUCN criteria, this species would currently be ranked as DD (data deficient). Although $M$. chartacea is known from only several collections, we expect this new species to have a wider distribution across the northern Amazon basin and on the Guiana Shield. Future research may show that a threatened classification (IUCN, 2016) is appropriate.

Additional specimens examined: BRAZIL. Amazonas: Basin of Rio Madeira, Humayta, near Livramento, on Rio Livramento, Oct--Nov 1934 [fr] Krukoff 6689 (A, NY); Humayta, on plateau between Rio Livramento and Rio Ipixuma, Nov 1934 [fr], Krukoff 7143 (GH, NY); Rio Madeira, Humaitá, road Humaitá to Porto Velho, Km 27, Nov 1966 [fr], Prance, Pena \& Ramos 3495 (GH, K, NY, US); Manaus and vicinity, road Igarape Leão, $25 \mathrm{~km} \mathrm{~N}$ of Manaus, Nov 1966 [fr], Prance, Pena \& Ramos 3142 (GH, NY). COLOMBIA. Caquetá: P. N. N. Serranía Chiribiquete, upper Río Mesay, ca. $10 \mathrm{~km}$ from Jacameya rapids, $0^{\circ} 04^{\prime} 50^{\prime \prime} \mathrm{N}$; 72 $2^{\circ} 25^{\prime} 37^{\prime \prime} \mathrm{W}$, Oct 2016 [fr], Restrepo C. 897 (COAH); Araracuara, Villa Azul, Muinane community, 0 32' S; 72 06' W, 300--350 m, May 1992 [fr], Duque \& Matapi 1743 (COL). Meta: Macarena, headwaters of río Tunia, Resguardo Indigena Yaguará, $01^{\circ} 43^{\prime} 39^{\prime \prime} \mathrm{N}$; 73 31' 34"' W, 280 m, Sep 2016 [fr], Cárdenas L., Marín, Paky, Aldana \& Paki 47331 (COAH). Vaupés: Taraira, E. B. Mosiro Itajura (Caparú), 01 ${ }^{\circ} 04^{\prime} 21.8^{\prime \prime} \mathrm{S}$; 69 31' 2.9' W, 200 m, Apr 2004, Clavijo-R., González \& Tanimuka 788 (COL). VENEZUELA. Amazonas: High Orinoco, río Metacuni, base of Sedukerawa Tepui, $03^{\circ} 15^{\prime} \mathrm{N}$; $64^{\circ} 56^{\prime} \mathrm{W}$, 210--650 m, Jan 1990 [fr], Stergios \& Velazco 14270 (NY, PORT); Atabapo, río Cunucunuma, torrente Picure, $03^{\circ} 43^{\prime}$ 40" N; 65 48' 40" W, 150 m, Jul 1992 [fr], Pérez \& Sosa 338 (MO). Bolívar: Cedeño, along río Erebato, $05^{\circ} 20^{`} \mathrm{~N}$; $64^{\circ} 45^{\prime}$ W, 330 m, Mar 1992 [fr], Boom \& Marín 10478 (NY, PORT). Delta Amacuro: Sierra Imataca, E side of río Cuyubini, Cerro La Paloma, 100--200 m, Nov 1960 [fr], Steyermark 87617 (NY, US, VEN)

Key to the species of Moutabea

1. Leaves distinctly coriaceous to very thick-textured, unicolored or sometimes discolored when dried, the lateral veins not discernible or distinctly and uniformly impressed .. 2

2. Branches and branchlets unarmed ............................ 3

3. Leaves oblong-obovate or oblong-lanceolate, inflorescences stout, 3--4 cm long, 2--3 mm wide, flowers ca. 2.5 $\mathrm{cm}$ long, sepals deltoid-ovate, acute at the apex, margins not ciliate...... M. chodatiana Huber (Brazil, possibly Venezuela)

3. Leaves obovate to elliptic, inflorescences slender, 1.5--3 cm long, ca. $1 \mathrm{~mm}$ wide, flowers $1.5--2 \mathrm{~cm}$ long, sepals ovate, round at the apex, margins ciliate ........... $M$. guianensis Aubl. (Brazil, Colombia, Ecuador, Guianas, Perú, Venezuela)

2. Branches and branchlets armed 4

4. Leaves narrowly oblong or oblong-obovate; petioles slender, ca. $1 \mathrm{~mm}$ wide; sepals narrowly ovate or oblong at the apex; filament sheath densely pilose externally ........ $M$. angustifolia Huber (Brazil) 
4. Leaves oblong, oblong-lanceolate or obovate-elliptic; petioles stout, 2--3 mm wide; sepals acute at the apex, filament sheath sparsely pilose externally ........................... 5

5. Leaves oblong to oblong-lanceolate; inflorescences $1--2 \mathrm{~cm}$ long; filament sheath ca. $1 \mathrm{~cm}$ long, pubescent externally, anthers subsessile, ca. $2 \mathrm{~mm}$ wide, rounded; ovary globose ................ M. dibotrya Mart. ex Miq. (Brazil)

5. Leaves obovate-elliptic; inflorescences $2.5--4 \mathrm{~cm}$ long; filament sheath ca. $1.5 \mathrm{~cm}$ long; anthers sessile, ca. $1 \mathrm{~mm}$ wide, circular; ovary pyriform .............. M. excoriata Mart. ex Miq. (Brazil)

1. Leaves chartaceous to coriaceous, always discolorous, brown abaxially, green and lustrous adaxially, the secondary veins slightly impressed to plane above, raised below ........ 6

6. Lower surfaces of the leaves velutinous ................. $M$. arianiae Jans.-Jac. \& Maas (Brazil, French Guiana)

6 . Lower surfaces of the leaves glabrous or minutely puberulent

7. Stout spinules sparse along the branches, rarely absent, leaves $13--35 \mathrm{~cm}$ long, without cystolith-like protuberances

... 8

8. Inflorescences monad, staminal sheath back of the staminal sheath hood partially free from the opposed petal .......... M. aculeata (Ruiz \& Pav.) Poepp. \& Endl. (Bolivia, Brazil, Colombia, Ecuador, Guianas, Perú, Venezuela)

8. Inflorescences tri- or tetramerous, back of the staminal sheath hood completely free from the opposed petal ....... $M$. floribunda J.C. Huber ex J.B. Silveira \& Secco (Brazil, Guayana, Perú)

7. Branches with or without persistent spinules, leaves 5--23 cm long, with cystolith-like protuberances ............... 9

9. Branches without persistent spinules, petioles \pm smooth, 1(--2) $\mathrm{mm}$ wide, leaves 2--3.5(--5) cm wide, calyx lobes oblong, 4--5 mm long, appressed pubescent on both surfaces, petal apices not reflexed, anthers rounded M. chartacea Aymard \& L.M.Campb. (Brazil, Colombia, Venezuela)

9. Branches with scattered spinules, petioles rugulose, 2--4 mm wide, leaves $4--10 \mathrm{~cm}$ wide, calyx lobes ovate, 7--9 mm long, densely puberulous adaxially, petal apices strongly reflexed, anthers quadrate ....................... gentryi T.Wendt (Colombia, Costa Rica, Panamá, Venezuela)

\section{Acknowledgments}

The authors are grateful to Bruno Manara (VEN) for preparing an early illustration and for his help with the Latin diagnosis; to Bobbi Angell for enhancements of the illustration; to Thomas (Tom) Wendt (TEX), who kindly provided the first author with his personal notes on Moutabea gathered during decades of herbarium specimen research, and to J. Richard Abbott (NY) and T. Wendt for their useful comments on the drafts of the manuscript. We thank the staff of the herbaria cited above for making their facilities available for our research.

\section{Author's contributions}

Both authors contributed equally to this work

\section{Conflicts of interest}

The authors declare no competing interests.

\section{References}

Angiosperm Phylogeny Group [APG] IV. (2016). An update of the Angiosperm Phylogeny Group classification for the orders and families of flowering plants: APG IV. Botanical Journal of the Linnean Society. 181: 1-20.

Aublet, J. B. C. F. (1775). Histoire des Plantes de la Guiana Françoise. p. 678-682. Vol. 2. P. F. Didot-jeune, London \& Paris.

Aymard, G., Berry, P., Eriksen, B. (2004). Polygalaceae. Pp. 316-347. In: Steyermark, J. A., Berry, P. B., Yatshievych, K. \& Holst, B. (editors.). Flora of Venezuelan Guayana. Vol. 8. Missouri Botanical Garden Press, St. Louis

Aymard, G. \& Freire-F., A. (2016). Polygalaceae. Pp. $2207-$ -2214. In: Bernal, R., Gradstein, S. R. \& Celis, M. (editors.). Catálogo de Plantas y Líquenes de Colombia. Vol. 2. Instituto de Ciencias Naturales, Universidad Nacional de Colombia, Bogotá. Accessed on: December 20, 2017. Available from: http://catalogoplantascolombia. unal.edu.co

Christenhusz, M. J. M., Fay, M. F., Byng, J. W. (2018). The global flora: A practical flora to vascular plant species of the world. Special Edition, GLOVAL nomenclature, 1 (4): 1-455. Plant Gateway, UK. Accessed on: July 25, 2018. Available from: www.plantgateway.com/global-flora

Eriksen, B. (1993a). Floral anatomy and morphology in the Polygalaceae. Plant Systematics and Evolution. 186: 17-32.

Eriksen, B. (1993b). Phylogeny of the Polygalaceae and its taxonomic implications. Plant Systematics and Evolution. 186: $33-55$.

Eriksen, B., Ståhl, B., Persson, C. (2000). Polygalaceae. Pp. 2-130. In: Harling, G. \& Andersson, L. (editors.). Flora of Ecuador. Vol. 65. Göteborg University, Sweden.

Eriksen, B. \& Persson, C. (2007). Polygalaceae. Pp. 345--363. In: K. Kubitzki (editor). The Families and Genera of Vascular Plants. Vol. 9. Springer-Verlag, Berlin.

Forest, F., Chase, M. W., Persson, C., Crane, P. R., Hawkins, J. A. (2007). The role of biotic and abiotic factors In evolution of ant dispersal in the Milkwort family (Polygalaceae). Evolution. 61: 1675-1694

International Union for the Conservation of Nature. (2016). Guidelines for using the IUCN red list categories and criteria. Version 12. Prepared by the Standards and Petitions Subcommittee. IUCN, Gland, Switzerland and Cambridge, England. Accessed on: Octuber 16, 2017. Available from: http://www.iucnredlist.org/documents/ RedListGuidelines.pdf

Jansen-Jacobs, M. J. \& Maas, P. J. M. (2010). Moutabea arianae, a new species of Polygalaceae from French Guiana and adjacent Brazil. Blumea. 55: 86-87.

Pastore, J. F. B., Abbott, J. R., Neubig, K. M., Whitten, M. W., Mascarenhas, R. B., Almeida-Mota, M. C., van den Berg, C. (2017). A molecular phylogeny and taxonomic notes in Caamembeca (Polygalaceae). Systematic Botany. 42: $54-62$ 
Persson, C. (2001). Phylogenetic relationships in the Polygalaceae based on plastid DNA sequences from the $t r n L-F$ region. Taxon. 50: 763-779.

Persson, C. \& Eriksen, B. (2009, onwards). Neotropical Polygalaceae. Neotropikey---Interactive key and information resources for flowering plants of the Neotropics. In: W. Milliken, B. Klitgård \& A. Baracat, A. (editors). Accessed on: November 11, 2017. Available from: http://www.kew.org/ science/tropamerica/neotropikey/families/Polygalaceae.htm

Ripardo Filho, H. S., Pacheco, L. C., Andrade, E. S., Correa, M. J. C., Araújo, R. N. M., Guilhon, G. M. S. P., da Silva, J. K. R., Santos, L. S. (2005). Xanthones from the roots of Moutabea guianensis Aubl. Molecules. 20: 127-134.

Ripardo Filho, H. S., Guilhon, G. M. S. P., Santos, L. S. (2014). A new Xanthone from Moutabea guianensis Aubl. Molecules. 19: $8885-8889$.

Silveira, B. J. \& Secco, R. S. (2015). A new species of Moutabea (Polygalaceae) for the Brazilian Amazon, Guyana and Perú. Phytotaxa. 202: 259-265.
Styer, C. H. (1977). Comparative anatomy and systematics of Moutabeae (Polygalaceae). Journal of the Arnold Arboretum. 58: 109-145.

Ulloa-Ulloa, C., Acevedo-R., P., Beck, S., Belgrano, M. J., Bernal, R., Berry, P. E., Brako, L., Celis, M., Davidse, G., Forzza, R. C., Gradstein, S. R., Hokche, O., León, M., León-Yánez, S., Magill, R. E., Neill, D. A., Nee, M., Raven, P. H., Stimmel, H., Strong, M. T., Villaseñor, J. L., Zarucchi, J. L., Zuloaga, F. O., Jørgensen, P. M. (2017). An integrated assessment of the vascular plant species of the Americas. Science. 358: 1614-1617.

Wendt, T. 2000. Moutabea gentryi (Polygalaceae), a new species of liana from Central America and Colombia. Lundellia. 3: 6-12.

Williams, C. A., Harborne, J. B. \& Colasante, M. (2000). The pathway of chemical evolution in bearded iris species based on flavonoid and xanthone patterns. Annali di Botanica. 58: $51-54$. 